\title{
Effects of sea urchin (Diadema setosum) gonad extracts on gene expression of FOXP3 and the production of cytokine on Salmonella typhi-induced mice
}

\author{
Wa Ode Salma ${ }^{1 *}$, Sitti Wahyuni ${ }^{2}$, Nursin Kadir $^{3}$, Suryani As'ad ${ }^{4}$, Irawan Yusuf ${ }^{5}$ \\ ${ }^{1}$ Department of Nutrition, Faculty of Medicine, Halu Oleo University, Kendari, Indonesia. \\ ${ }^{2}$ Department of Parasitology, Faculty of Medicine, Hasanuddin University, Makassar, Indonesia. \\ ${ }^{3}$ Clinical Pathology Laboratory, Hospital Labuanbaji, Makassar, Indonesia. \\ ${ }^{4}$ Department of Nutrition, Faculty of Medicine, Hasanuddin University, Makassar, Indonesia. \\ ${ }^{5}$ Department of Physiology, Faculty of Medicine, Hasanuddin University, Makassar, Indonesia.
}

\begin{tabular}{|c|c|}
\hline ARTICLE INFO & ABSTRACT \\
\hline $\begin{array}{l}\text { Received on: } 15 / 07 / 2018 \\
\text { Accepted on: } 26 / 10 / 2018 \\
\text { Available online: } 30 / 12 / 2018\end{array}$ & $\begin{array}{l}\text { The gonad of the sea urchin, Diadema setosum, is highly nutritious and has demonstrated the importance for the } \\
\text { regulation of inflammation response. However, no previous research study has evaluated the capacity of sea urchin } \\
\text { gonads to regulate the inflammatory response. Our objectives were to examine the effect of gonad extracts of } \\
\text { D. setosum on the expression of mRNA FoxP } 3 \text { gene and the production of cytokine interferon-gamma (IFN-g) and }\end{array}$ \\
\hline $\begin{array}{l}\text { Key words: } \\
\text { Diadema setosum, gonad, } \\
\text { mRNA FoxP3, cytokine, } \\
\text { Salmonella typhi. }\end{array}$ & $\begin{array}{l}\text { interleukin-10 (IL-10) in mice after the induction of lipopolysaccharide (LPS) using Salmonella typhi. Fifteen male } \\
\text { mice were divided into two groups (intervention and control), before and after intraperitoneal injection of } S \text {. typhi. } \\
\text { The intervention group was treated with two dosages of the extracted gonad ( } 100 \text { and } 200 \mathrm{mg} / \mathrm{kg} \text { of body weight). } \\
\text { The control group was fed with the natural diet only. We found that the expression of gene FoxP3 and production of } \\
\text { cytokine exhibited a short decrease after } 24 \text { hours of LPS induction and then returned to pre-induction levels. Notably, } \\
\text { the expression of FoxP3 and production of IFN-g in the control group continued to decline significantly until day } \\
\text { 7. Conversely, the production of IL-10 continued to increase significantly. We conclude that the gonad extract of } \\
\text { D. setosum is effective for the regulation of immune response and it has strong potential to be developed as a dietary } \\
\text { supplement for acute and chronic inflammation. }\end{array}$ \\
\hline
\end{tabular}

\section{INTRODUCTION}

One of the primary expressions in the immune system is the ability to undertake inflammation reaction to the presence of pathogen stimulation. However, if an over-inflammation reaction occurs, it will result in a number of chronic inflammatory diseases (Bordoni et al., 2017). Cytokine of IL-10 and IFN- $\gamma$ secreting $\mathrm{CD} 4+\mathrm{T}$ cells are activated during chronic infections and are responsible for the prolonged persistence of microbes and for host protection against severe inflammatory responses (Flores-García et al., 2011). During infection, the immune system requires control

\section{"Corresponding Author}

Wa Ode Salma, Department of Nutrition, Faculty of Medicine, Halu Oleo University, Kendari, Indonesia.E-mail: waode.salma.fkuho@gmail.com of the immune response (Belkaid, 2007). FoxP3 (forkhead box P3) is a DNA-binding protein that regulates transcription for the development and survival of $\mathrm{T}$ regulatory cells (Liston and Gray, 2014). The function of the cells is to control over-inflammation and prevent tissue destruction (Josefowicz et al., 2012). The depletion and loss of FoxP3 expression cause the reduced function of T regulatory cells (Milanez-Almeida et al., 2015).

Micronutrient contents in cells can maintain the function of the immune system (Mocchegiani et al., 2014). Nutrient contents in the diet, such as vitamins A, B9, polyunsaturated fatty acids (PUFA), and flavonoids, in the diet induce the deferential of $\mathrm{T}$ regulatory cells, thereby suppressing chronic inflammatory diseases (Kim and Lee, 2013). Components of certain nutrients in the diet may increase the expression of mRNA FoxP3 (IssazadehNavikas et al., 2012). 
Gonads of the sea urchin, D. setosum, is a source of seafood which has been known for high levels of vitamins A and E (Salma et al., 2016a), oleic acid, glutamine, arginine, and PUFA (Delianis et al., 2016), compared with salmon, mackerel, anchovies, sardines, chicken eggs, and shrimps. No previous research has examined the potential for the use of sea urchin gonads to regulate the inflammatory response. Based on the known nutritional components of the gonad of D. setosum, we hypothesized that the gonads of $D$. setosum possess the capacity for inflammatory regulation. The purpose of our research study was to examine the effects of extracted gonad of D. setosum on the expression of the FoxP3 gene (mRNA FoxP3) and cytokine (IFN-g and IL-10) on mice BALB/c infected by S. typhi. Our goal was to identify a potential new food source for immune regulation and control of chronic inflammation.

\section{MATERIALS AND METHODS}

\section{Sampling location and extraction of D. setosum gonad}

Sea urchin was collected from Wakatobi Island, Southeast Sulawesi, and the gonad was extracted in the Department of Pharmacy, University of Hasanuddin, Makassar, Sulawesi, Indonesia. The extraction was performed based on a method developed by Salma et al. (2016b). Briefly, $500 \mathrm{~g}$ of dried gonad was extracted using 2,500 $\mathrm{ml}$ of acetone and then kept in the dark for 24 hours. The extraction procedure was done several times until the sample became clear in color. Afterward, the extracted samples were steamed using rotavapor with a temperature of $45^{\circ} \mathrm{C}$ to obtain free acetone extraction.

\section{Animals and treatments}

We used 12-week old mice, free of pathogens, from the Laboratory of Biomolecular and Immunology of Medical Faculty of University of Hasanuddin, Makassar. They were fed with standardized diet ad libitum and kept in a controlled temperature of $23^{\circ} \mathrm{C}$, humidity of $50 \%$, and exposed to light for 12 hours per day. This research study was approved by the Health Medical Research Ethics Committee at the Faculty of Medicine, Hasanuddin University (Makassar, Indonesia) with the registration number UH15020068-Kometik/2015.

A total of 15 mice with a weight of $30-40 \mathrm{~g}$ were selected for the research study. Mice were divided into two groups: the first contained those without extraction (control) and the second included those treated with gonad extraction $(100 \mathrm{mg} / \mathrm{kg}$ of body weight and $200 \mathrm{mg} / \mathrm{kg}$ of body weight). Process and the observation of immune response of $\mathrm{BALB} / \mathrm{c}$ mice were done for 17 days based on its category. After blood collection, mice were treated with extracted gonad of $D$. setosum with different dosages. The treatments were $100 \mathrm{mg} / \mathrm{kg}$ of body weight and $200 \mathrm{mg} / \mathrm{kg}$ of body weight administered orally through cannula on a daily basis. It is according to the research method which conducted by Salma et al. (2016b).

Process and examination of the immune response of $\mathrm{BALB} / \mathrm{c}$ mice were performed for 17 days. After blood collection, the intervention groups were treated with $100 \mathrm{mg} / \mathrm{kg} / \mathrm{day}$ and $200 \mathrm{mg} / \mathrm{kg} /$ day of extracted gonad orally using cannula. After 10 days of intervention, blood was taken from the three groups, and then mice were left to rest for 3 hours. The groups were then stimulated by intraperitoneal injection of lipopolysaccharide (LPS; $0.2 \mathrm{ml} \times 10^{3} \mathrm{ml} / \mathrm{CFU}$ ) of $S$. typhi. Mice blood is taken again after 24 and 72 hours and 7 days after stimulation of LPS. A $0.2 \mathrm{ml}$ sample of blood was collected through the tail using insulin syringe of $1 \mathrm{ml}$.

\section{Measurement of cytokine by ELISA}

Serum was kept in a $-20^{\circ} \mathrm{C}$ freezer and prepared when cytokine was measured using enzyme-linked immunosorbent assay (ELISA). Cytokine IFN-g was measured using an ab46081 IFN-g Mouse Elisa kit and cytokine IL-10 was measured using an ab46103-IL-10 Mouse Elisa kit. Briefly, a $0.2 \mathrm{ml}$ mice blood sample was placed in a 5-ml vacuum tube to which EDTA K3 had been added.

The tube was centrifuged at $1,000 \mathrm{rpm}$ for 10 minutes, which allowed the blood cells to settle. The clear solution was collected and transferred to an Eppendorf tube with a concentration of $0.5 \mathrm{ml}$. Serum was diluted using a standard solvent with a ratio of 1:500 (1 $\mu \mathrm{l}$ serum $+99 \mu \mathrm{l}$ solvent). To determine the level of IFN-g and IL-10, a 96-well microplate Elisa was prepared. The anti-IFN- $g$ and anti-IL-10 were transferred into the microplate and then $100 \mu \mathrm{l}$ of coating antibody were added to each well made with a dilution of $5 \mu \mathrm{l}$ in $2.5 \mathrm{ml}$. Then, the samples were incubated at ambient temperature for 18-24 hours, washed with $300 \mu \mathrm{l}$ wash buffer to remove displaced antibody, and added with $100 \mu \mathrm{l}$ NHS (N-hydroxysuccinimide) in every well sample. A $50 \mu \mathrm{l}$ biotin conjugate was added and incubated for 1 hour at ambient temperature. The good microplate was washed three times using $300-\mu 1$ wash buffer to remove displaced antibody from the samples. Next, TMB (tetramethylbenzene) substrate was added and incubated in the dark for 15 minutes. TBM substrate caused the reaction to turn blue in color and ceased the reaction by the addition of sulfuric acid. At the end of the reaction, the color changed to bright yellow. The final process was ELISA reader conducted by using spectrophotometer with a wavelength of $450 \mathrm{~nm}$.

\section{RNA extraction}

Total of mRNA was isolated from blood samples using the Boom method (1990). A 20- $\mu$ l diatom suspension (silica) was added to a 100- $\mu$ l sample of blood and diluted with $900 \mu \mathrm{l}$ of the lysis buffer L6. This solution was vortexed and centrifuged at $13,000 \mathrm{rpm}$ for 15 seconds. The supernatant was then discarded and the sediment was purified twice using $500 \mu \mathrm{l}$ of lysis buffer L2 (vortexed and centrifuged for 15 seconds). Purification was conducted twice using $500 \mu \mathrm{l}$ of $70 \%$ ethanol (vortexed and centrifuged for 15 seconds). We conducted the final purification using $500 \mu \mathrm{l}$ of acetone. The solution obtained from purification was incubated with a heating block at a temperature of $56^{\circ} \mathrm{C}$ for 10 minutes. Buffer solution (TE) was added, the resulting solution was vortexed and centrifuged at 13,000 rpm for 2 minutes producing DNA extraction. A $20-\mu \mathrm{l}$ sample of extracted DNA was collected, placed in the tube, and kept in a $-80^{\circ} \mathrm{C}$ freezer.

\section{Quantitative real-time PCR assay}

Quantitative real-time PCR system (Applied Biosystems) using Power SYBR ${ }^{\circledR}$ was used with the following reagents: a forward primer of FOXP3 was FW-TTTACTCGCATGTTCGCCTACTT and reverse primer was RV-TCAAATTCATCTACGGTCCACATC. (NM_00199347.1) and normality standard was GAPDH FW-CA 
TGGCCTTCCGTGTTCCT and RV-GCGGCACGTCAGATCCA (Takeuchi et al., 2013). Thermal cycling was undertaken for 30 seconds using the following cycling parameters: extension at a temperature of $95^{\circ} \mathrm{C}$, followed by 40 cycles of denaturation for 10 seconds at a temperature of $95^{\circ} \mathrm{C}$, annealing at $60^{\circ} \mathrm{C}$ for 15 seconds, and then extension for 40 seconds at a temperature of $72^{\circ} \mathrm{C}$. The examination of PCR results was conducted three times and data were analyzed using a detection instrument Mx4000 with the comparative threshold cycle method. The standard curve was made and became an indication of efficiency in amplification (90\%-100\%).

\section{Statistical analysis}

Results were summarized as the mean \pm standard deviation (SD). We used a repeated measures analysis of variance to compare IFN-g and IL-10 and expression of mRNA FoxP3 between the control group and the group treated with gonad. We used a separate $t$-test to compare IFN-g and IL-10 and expression of mRNA FoxP3 between the two doses. Data were analyzed with SPSS statistical software (version 23.0). Statistical significance was considered as $p<0.05$.

\section{RESULTS AND DISCUSSION}

Selected extracted gonad as 100 and $200 \mathrm{mg} / \mathrm{kg}$ of body weight and continued for 17 days, the nutrients contained in the gonad extracted from $D$. setosum are probably better to induce the IFN- $\gamma$, IL-10 cytokine immune responses and expression of FOXP3 gene to provide initial defense when pathogens can escape into the body. Our previous research study, after 10 days of intervention, blood was taken from the three groups, and then mice were left to rest for 3 hours. The groups were then stimulated by intraperitoneal injection of LPS $\left(0.2 \mathrm{ml} \times 10^{3} \mathrm{ml} / \mathrm{CFU}\right)$ of $S$. typhi. Blood from mice wereas taken again 7 days after stimulation of LPS (Salma et al., 2016b). The phase of the adaptive immune response after exposure to the antigen was on the 7 th day lymphocyte activity (antibody production and effector $\mathrm{T}$ cell lymphocytes) occurs, day 14 antigen was eliminated and entering the 21 st day there is an apoptosis from effector lymphocyte cells for homeostasis and surviving memory cells (Abbas et al., 2012).

\section{IFN-g and IL-10 productions in control and intervention groups}

We found no difference in the level of IFN-g between intervention and control before the induction of LPS. However, the IFN-g in intervention groups decreased after 24 hours post induction to return to normal (Fig. 1). Interestingly, the level of IFN-g in the control group continued to decrease until the 7 th day of observation.

The level of IL-10 in intervention and control groups was not different before the induction of LPS. But, we found that the level reduced in the intervention group after 24 hours post induction. Meanwhile, the level of IL-10 in the control group constantly increased until the 7th day of examination (Fig. 2).

There was no difference in the production of IFN-g and IL-10 in mice in the interventions group treated with 100 and 200 $\mathrm{mg} / \mathrm{kg}$ before the induction of LPS $(p>0.05)$. After the induction, the production of IFN-g and IL-10 differed $(p<0.05)$ after the 7 th day of observation. Group treated with $200 \mathrm{mg} / \mathrm{kg}$ more significantly influenced inflammatory regulation compared with the group treated with $100 \mathrm{mg} / \mathrm{kg}$ (data were not available).

A dynamic stabilization between pro- and antiinflammation of cytokine would prevent a host from deterioration as a result of over-inflammation (Hurley et al., 2014). IFN-g is an essential cytokine for pro-inflammation as it has an important function in intracellular cell-mediated immunity (Abbas et al., 2012). The IFN-g ranks among the most important endogenous regulators of immune responses (Billiau and Matthys, 2009). Lack of IFN-g production decreases neutrophil mobility and the activity

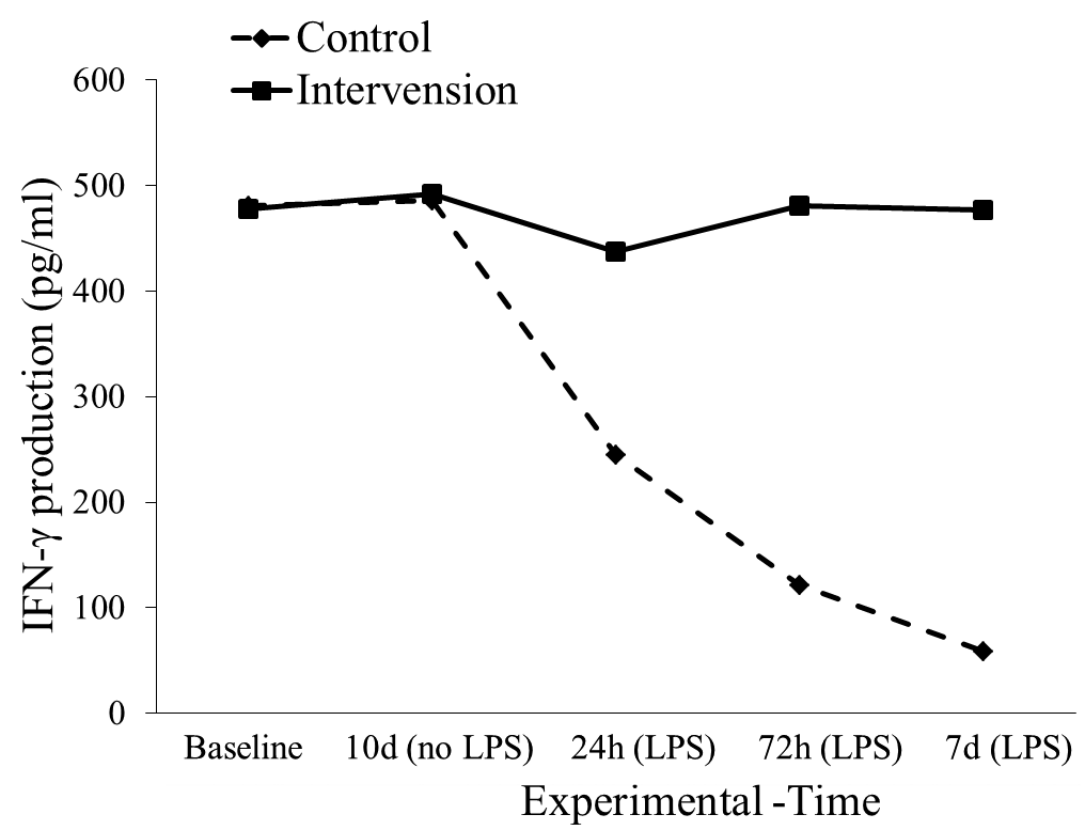

Figure 1. The dynamics of interferon gamma production at $0,24,72$ hours, and 7 days after $S$. typhi stimulation in control and intervention groups. 


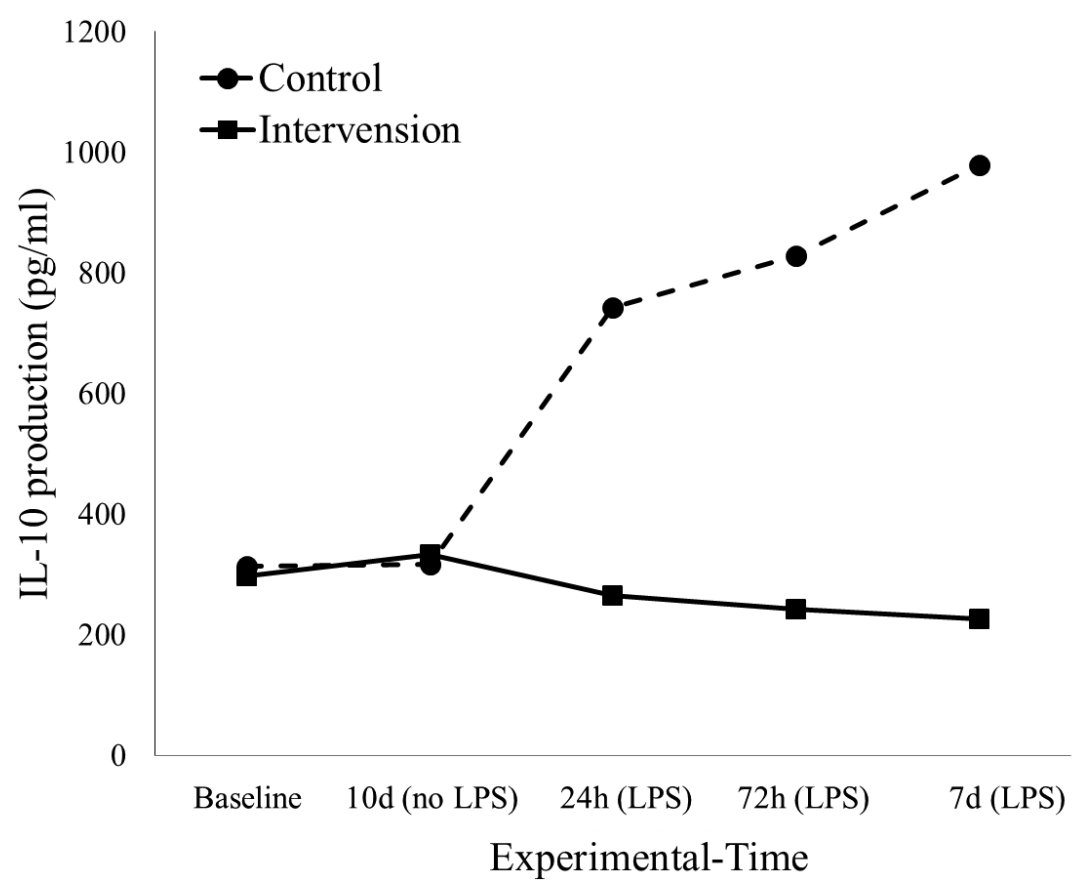

Figure 2. The dynamic of interleukin-10 productions at 24, 72 hours, and 7 days before $S$. typhi stimulation in control and intervention groups.

of natural killer cells, which indicate a heavy infection (Mócsai, 2013). On the contrary, overproduction of cytokine IFN-g causes inflammation due to the release of toxic metabolites (Schroder et al., 2004). Anti-inflammation of IL-10 suppresses the overreaction of pro-inflammation (Couper et al., 2008). Furthermore, if over-production of cytokine IL-10 occurred, it will directly prevent the function of antigen percentile cells, inhibit the development of T CD4 cells to produce IFN-g effector, and eventually fail to control heavy infection (Ndishimye et al., 2015).

We revealed the effect of extracted gonad of $D$. setosum on the immune response of mice $\mathrm{BALB} / \mathrm{c}$ in the intervention group, which indicated the stable production of cytokine IFN-g after the 7 th day of observation. It was expected that cytokine was active earlier than 24 hours and maybe cytokine is an important for the removal of $S$. typhi at the infection stage. Therefore, we speculated that the nutrients contained in the gonad were particularly important for an innate immune response as an anti-oxidant and anti-biotic to induce cytokine IFN-g in order to eradicate gram-negative bacteria, such as $S$. typhi. The production of IL-10 in the intervention group, however, slightly decreased and was constant. It was expected that the quantity of required cytokine was minimal, which indicated that the anti-inflammation of IL-10 did not dominate the suppression of IFN-g. Therefore, IFN-g remained functional.

Our observations of the control group showed that the stimulation of LPS of $S$. typhi caused the low production of cytokine IFN-g, while the stimulation of $S$. typhi in the group contributed to the high production of cytokine IL-10 until the 7th day of the experiment. This condition indicated that over-inflammation reaction occurred. The bacterium $S$. typhi has the ability to invade widely and cause chronic and acute infection because it can replicate and survive from phagocyte of epithelial, dendritic cells, and macrophage from the immune system (Gunn et al., 2015). Reduced response to inflammation due to the infection of S. typhi resulted in widespread persistence of infection and facilitated longer survival of the pathogen (Merrell and Falkow, 2004). We found that higher loading of $S$. typhi resulted in the inhibition of effector of T cell activation (Johanns et al., 2010). It is generally known that the response of the innate immune system occurs in 12 hours and stronger adaptive immune response will remain active thereafter (Abbas et al., 2012). However, the occurrence of high inflammation reaction will impede the development of CD4 producing IFN-g cytokine effector and the depletion in cytokine of IFN-g results in a heavy infection (Abbas et al., 2012). Our findings were consistent with the previous studies by Singh and Thirumalapura (2014) who conducted a similar experiment in six mice C57BL type infected by LPS of Ehrlichia muris. Their finding shows the concentration level of IL-10 increased significantly in day 8 and indicated that specific function of T cell CD4 gradually decreased and lost the ability to produce cytokine IFN-g effector (Singh and Thirumalapura, 2014). Deficiency of micronutrients in the diet leads to the immune destruction that eventually affects innate and adaptive responses (Bresnahan and Tanumihardjo, 2014).

\section{Expression of $m R N A$ FoxP3 in control and intervention groups}

The expression of mRNA FoxP3 in both the intervention and control group was different before the induction of LPS. The expression in the intervention group, however, decreased after 24 hours post induction $(p=0.335)$ and then the level returned to normal in the 7 th day after induction $(p<0.05)$. Interestingly, the expression of mRNA FoxP3 in the control group continued to decrease significantly after 72 hours to the 7 th day of observation (Fig. 3). 


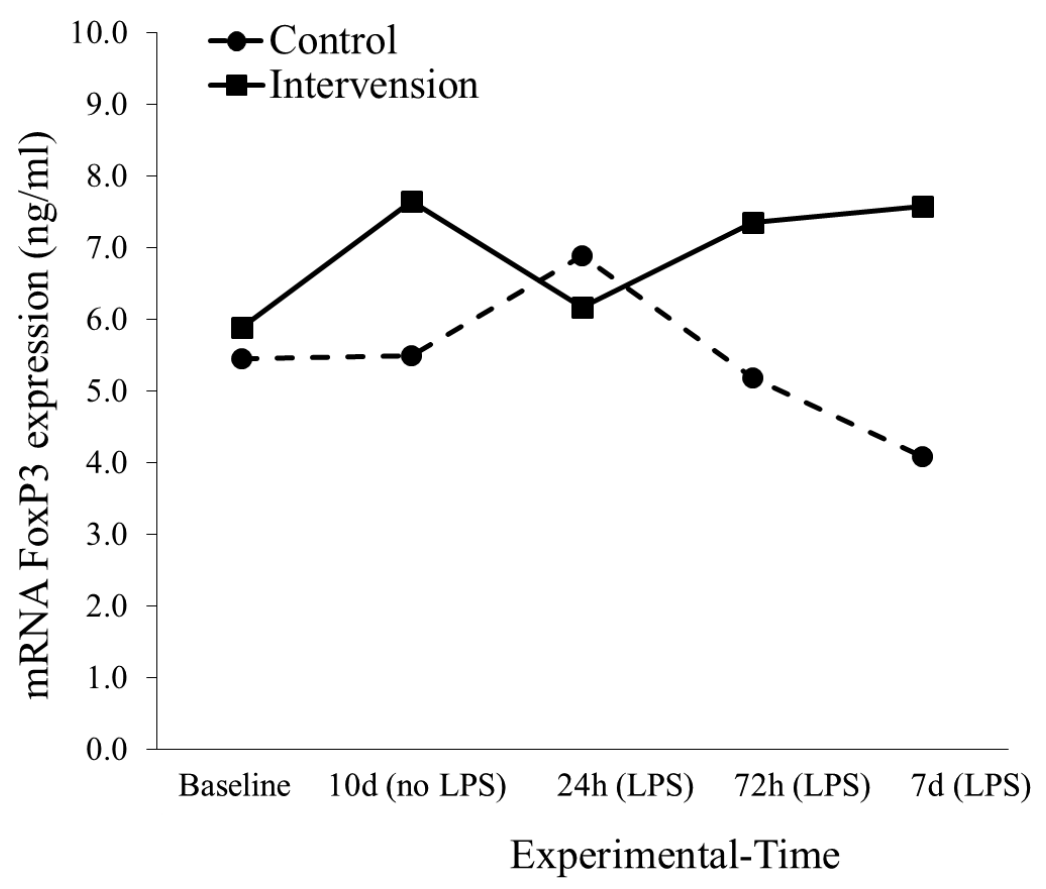

Figure 3. The dynamic of mRNA FoxP3 expression at 24, 72 hours, and 7 days before S. typhi stimulation in control and intervention groups.

We observed no difference in the intervention group treated with 100 and $200 \mathrm{mg} / \mathrm{kg}$ on the expression of mRNA FoxP3 of mice before the induction of LPS $(p>0.05)$. After the induction, the expression of mRNA FoxP3 after the 7th day of observation differed $(p<0.05)$. The group treated with $200 \mathrm{mg} / \mathrm{kg}$ exhibited higher inflammatory regulation compared with the group treated with $100 \mathrm{mg} / \mathrm{kg}$ (data were not available).

$\mathrm{T}$ regulatory cells are produced in the thymus and possess indicator molecules such as $\mathrm{CD} 4{ }^{+} \mathrm{CD} 25^{+} \mathrm{FoxP} 3$ (Katoh et al., 2013). The cells may affect the Th1 and Th2 through cytokine and direct contact between cells (Kessel et al., 2012). T regulatory cells of FoxP3 contribute to the controlling activity of $\mathrm{T}$ helper cells, possess related function in the blood and tissues, and become an indicator of novel gene activity (Dhuban et al., 2014). Depletion of S. typhi is associated with strong effector of T regulatory cells. Therefore, the cells have the potential to determine the spread of persistent infection (Johanns et al., 2010). Previous research studies found that certain nutrients in the diet increased the expression of $\mathrm{T}$ regulatory cells of FoxP3. The depletion in the expression of the FoxP3 gene is associated with the reduced ability of $T$ regulatory cells. Sufficient nutrients are a source of energy for $\mathrm{T}$ regulatory cells of FoxP3 to regulate the immune system (Kinoshita and Takeda, 2014). Nutritional contents such as antioxidant, vitamins $\mathrm{A}, \mathrm{C}, \mathrm{E}$, minerals $\mathrm{Zn}$ and $\mathrm{Mg}$ from propolis trigona may increase the expression of mRNA FoxP3 in mice BALB/c infected by S. typhi (Usman et al., 2016). In our research study, the intervention of the gonad in mice BALB/c induced by LPS bacteria of $S$. typhi showed that mRNA FoxP3 had the ability to increase its expression back to normal after the 7th day of observation. This means that the function of regulatory $\mathrm{T}$ cells is maintained. Our previous research study identified that the gonad of $D$. setosum contained vitamins $\mathrm{A}$ and $\mathrm{E}$ and minerals iron $(\mathrm{Fe})$,
$\mathrm{Mg}$, and Zn, as well as albumin (Salma et al., 2016a). Certain nutrient components increase the expression of mRNA FoxP3 (Issazadeh-Navikas et al., 2012).

We determined in the present research study that the induction of LPS in the control group reduced the expression of gen FoxP3 after 72 hours to the 7 th day of the experiment (Fig. 3). This condition indicated that the reduction of gen FoxP3 expression might be caused by the poor ability of T regulatory cells in regulating inflammation. Thus, the reaction of over-inflammation in control group mice could not be avoided. It is probable that the effect of LPS $0.2 \mathrm{ml} \times 10^{3} \mathrm{CFU} / \mathrm{ml}$ administered through intraperitoneal injection induced a strong inflammatory reaction causing one of the treated mice to die in day 5. The present research study was compared with other research (Depaolo et al., 2005), where the induction of mice using $10^{4} \mathrm{C} 57 \mathrm{BL} / 6$ infected by $S$. typhi showed that around $40 \%$ mice survived through day 5 and around $20 \%$ to day 6 . The presence of an infectious agent leads to the aggressive attack of T regulatory cells resulting in the depletion of the cells and loss of its function as an immune regulatory response (Nair et al., 2013). The loss of T cells from the circulation system causes the loss of homeostasis and the degradation of the immune system (Zhao et al., 2006). The instability or loss of FoxP3 expression leads to the weaker functioning of T regulatory cells (Rudensky, 2012), (Loosdregt et al., 2012). The depletion of mRNA of T regulatory cells showed the importance of $\mathrm{T}$ cells in homeostatic and immune system maintenance (Baumjohann and Ansel, 2013).

\section{CONCLUSIONS}

It is interesting in our results, because, the decrease in FoxP3 mRNA expression is not in line with the decrease in IL-10 cytokines in the control group. There may be other mechanisms that regulate this phase because IL-10 is not only released by 
regulatory $\mathrm{T}$ cells but several other cell activities are also involved in producing IL-10 when the inflammatory reaction process occurs, for example, macrophage cells. Therefore, to find out which cells release IL-10, stimulation of PBMC (peripheral blood mononuclear cell) needs to be conducted in our trial because the blood volume of BALB/c mice can only be taken $0.2 \mathrm{ml}$. In addition to that, eliminating S.typhi and knowing homeostasis and memory are surviving is necessary to increase the intervention time. We conclude that the gonad of D. setosum exhibits inflammatory regulation and provides sufficient protection in the early defense against infectious microbes. Moreover, the gonad has the potential to be used as a food supplement for acute and chronic inflammation. We recommend that future research study is focused on the mechanism and application of our results to the development of natural products.

\section{ACKNOWLEDGMENTS}

We would like to express our gratitude to Dr. Safarina G. Malik, MS., PhD (Institution of Eijkman Molecular Biology, Jakarta, Indonesia). We would definitely thank Indonesia Ministry ofHealth and Ministry of Research and Technology, Risbin Iptekdok Project for their financial support (HK.05.01/1.1/1494/2015). Finally, we thank YBLI divers for sample collection.

\section{CONFLICT OF INTEREST}

The authors declare there is no conflict of interest in this study.

\section{REFERENCES}

Abbas AK, Lichtman AH, Pillai S. Cellular and molecular immunology. 7th edition, Elsevier Saunders, Philadelphia, USA, 2012.

Baumjohann D, Ansel KM. MicroRNA regulation of T helper cell differentiation and plasticity. Nat Rev Immunol, 2013; 13(9):666-78.

Belkaid Y. Regulatory $\mathrm{T}$ cells and infection: a dangerous necessity. Nat Rev Immunol, 2007; 7(11):875-88.

Billiau A, Matthys P. Interferon- $\gamma$ : a historical perspective. Cytokine Growth Factor Rev, 2009; 20(2):97-113.

Boom R, Sol C, Salimans MMM, Jansen CL, Wertheim-van Dillen PME, Noordaa JVD. Rapid and simple method for purification of nucleic acids. J Clin Microbiol, 1990; 28(3):495-503.

Bordoni A, Danesi F, Dardevet D, Dupont D, Fernandez AS, Gille D, Santos CND, Pinto P, Re R, Rémond D, Shahar DR, Vergères G. Dairy products and inflammation: a review of the clinical evidence. Crit Rev Food Sci Nutr, 2017; 57(12):2497-525.

Bresnahan KA, Tanumihardjo SA. Undernutrition, the acute phase response to infection, and its effects on micronutrient. Adv Nutr, 2014; 5(19):702-11.

Couper KN, Blount DG, Riley EM. IL-10: the master regulator of immunity to infection. J Immunol, 2008; 180(9):5771-7.

Delianis P, Ana A, Indriatmoko, Sri S, Dwi H. The potency of sea urchin (Diadema Setosum) gonad on brain cells of white rats (Rattus Norvegicus). Asian J Pharm, 2016; 10(2):100-7.

Depaolo RW, Lathan R, Rollins BJ, Karpus WJ. The chemokine CCL2 is required for control of murine gastric Salmonella enterica infection. Infect Immun, 2005; 73(10):6514-22.

Dhuban KB, Kornete M, Mason ES, Piccirillo CA. Functional dynamics of Foxp3 + regulatory T cells in mice and humans. Immunol Rev, 2014; 259(1):140-58.

Flores-García Y, Rosales-Encina JL, Satoskar AR, TalamásRohana P. IL-10-IFN- $\gamma$ double producers CD4 $+\mathrm{T}$ cells are induced by immunization with an amastigote stage specific derived recombinant protein of Trypanosoma cruzi. Int J Biol Sci, 2011; 7(7):1093-100.
Gunn JS, Marshall JM, Baker S, Dingol S, Charles RC, Ryan ET. Salmonella chronic carriage: epidemiology, diagnosis and gallbladder persistence. Trends Microbiol, 2015; 22(11):648-55.

Hurley D, McCusker MP, Fanning S, Martins M. Salmonellahost interactions - modulation of the host innate immune system. Front Immunol, 2014; 5:1-11.

Issazadeh-Navikas $\mathrm{S}$, Teimer $\mathrm{R}$, Bockermann $\mathrm{R}$. Influence of dietary components on regulatory T cells shohreh. Mol Med, 2012; 18(1):95-110.

Johanns TM, Ertelt JM, Rowe JH, Way SS. Regulatory T cell suppressive potency dictates the balance between bacterial proliferation and clearance during persistent Salmonella infection. PLoS Pathog, 2010; $6(8): 31-2$

Josefowicz SZ, Lu LF, Rudensky AY. Regulatory T cells: mechanisms of differentiation and function. Ann Rev Immunol, 2012; 30(1):531-64

Katoh M, Igarashi M, Fukuda H, Nakagama H, Katoh M. Cancer genetics and genomics of human FOX family genes. Cancer Lett, 2013; 328(2):198-206.

Kessel A, Haj T, Peri R, Snir A, Melamed D, Sabo E, Toubi E. Human CD19(+)CD25(high) B regulatory cells suppress proliferation of CD4+T cells and enhance Foxp3 and CTLA-4 expression in T-regulatory cells. Autoimmun Rev, 2012; 11(9):670-7.

Kim W, Lee H. Advances in nutritional research on regulatory T-cells. Nutrients, 2013; 5(11):4305-15.

Kinoshita M, Takeda K. Microbial and dietary factors modulating intestinal regulatory T cell homeostasis. FEBS Lett, 2014; 588(22):4182-7. Liston A, Gray DHD. Homeostatic control of regulatory T cell diversity. Nat Rev Immunol, 2014; 14(3):154-65; doi:10.1038/nri3605

Loosdregt JV, Fleskens V, Fu J, Brenkman AB, Bekker CPJ, Pal CE, Meerding J, Berkers CR, Barbi J, Gröne A, Sijts AJ, Maurice MM, Kalkhoven E, Prakken BJ, Ovaa H, Pan F, Zaiss DM, Coffer PJ Stabilization of the transcription factor Foxp3 by the deubiquitinase USP7 increases Treg-cell-suppressive capacity. Immunity, 2012; 32(4):445-55.

Merrell DS, Falkow S. Frontal and stealth attack strategies in microbial pathogenesis. Nature, 2004; 430(6996):250-6.

Milanez-Almeida P, Meyer-Hermann M, Toker A, Khailaie S, Huehn J. Foxp3+ regulatory T-cell homeostasis quantitatively differs in murine peripheral lymph nodes and spleen. Eur J Immunol, 2015; 45(1):153-66.

Mocchegiani E, Costarelli L, Giacconi R, Malavolta M, Basso A, Piacenza F, Ostan R, Cevenini E, Gonos ES, Monti D. Micronutrient gene interactions related to inflammatory/immune response and antioxidant activity in ageing and inflammation . a systematic review. Mech Ageing Dev, 2014; 136-137:29-49.

Mócsai A. Diverse novel functions of neutrophils in immunity, inflammation, and beyond. J Exp Med, 2013; 210(7):1283-99.

Nair S, Aldrich AJ, McDonnell E, Cheng Q, Aggarwal A, Patel P, Williams MM, Boczkowski D, Lyerly HK, Morse MA, Devi GR. Immunologic targeting of FOXP3 in inflammatory breast cancer cells PLoS One, 2013;8(1):1-11.

Ndishimye P, Seghrouchni F, Domokos B, Soritau O, Sadak A, Homorodean D, Aouada RE, Pop CM. Evaluation of interleukin-10 levels in the plasma of patients with various stages of tuberculosis. Clujul Med, $2015 ; 88(2): 164-7$

Rudensky AY. Regulatory T cells and Foxp3. Immunol Rev, 2012; 241(1):260-8.

Salma WO, Wahyuni S, Yusuf I, Haya LOMY, Yusuf I, As'ad S. Immunenutrientcontentofseaurchin(DiademaSetosum)gonads.IntJNutrFood Sci, 2016a; 5(5):330-6. Available via http://www.sciencepublishinggroup. $\mathrm{com} /$ journal/paperinfo?journalid=153\&doi=10.11648/j.ijnfs.20160505.13.

Salma WO, Hafizah I, Nurtamin T, Haya LOMY, As'ad S. The potential gonad of diadema setosum as a healthy food to improve the nutritional status of coastal's children. Int J Sci: Basic Appl Res, 2016b; 27(2):189-95. Available via http://gssrr.org/index. php?journal=JournalOfBasicAndApplied. 
Schroder K, Hertzog PJ, Ravasi T, Hume DA. Interferon-Y: an overview of signals, mechanisms and functions. J Leukoc Biol, 2004; 75:163-89.

Singh AK, Thirumalapura NR. Early induction of interleukin-10 limits antigen-specific CD4+ T cell expansion, function, and secondary recall responses during persistent phagosomal infection. Infect Immun, 2014; 82(10):4092-103.

Takeuchi T, Yoshida M, Shimizu T, Asano A, Shimokawa T, Nabeta M, Usui T. Differential expressions of toll-like receptor genes in the vagina of pregnant mice. J Vet Med Sci, 2013; 75(5):561-5.

Usman NA, Syam Y, Natzir R, Rahardjo SP, Hatta M, Dwiyanti $\mathrm{R}$, Widaningsih $\mathrm{Y}$. The effect of giving trigona honey and honey propolis trigona to the mRNA Foxp3 expression in mice Balb/c strain induced by Salmonella typhi. Am J Biomed Res, 2016; 4(2):42-5.
Zhao DM, Thornton AM, DiPaolo RJ, Shevach EM. Activated CD4+CD25+ $\mathrm{T}$ cells selectively kill B lymphocytes. Blood, 2006; 107(10):3925-33.

\section{How to cite this article:}

Salma WO, Wahyuni S, Kadir N, As'ad S, Yusuf I. Effects of sea urchin (Diadema setosum) gonad extracts on gene expression of FOXP3 and the production of cytokine on Salmonella typhi-induced mice. J App Pharm Sci, 2018; 8(12): 140-146. 